ーノートー

\title{
リチゥム金属／有機溶媒界面のその場顕微ラマン分光測定
}

伊藤隆, 松谷 晹子, 内田勇*

\section{Raman Microprobe Spectroscopic Study of Interfacial Species between Li and Organic Solvents}

Takashi ITOH, Youko MATSUTANI and Isamu UCHIDA*

Received August 2, 1995 ; Accepted September 5, 1995

1

リチウム 2 次電池の負霞材料々して用いら扎リチ

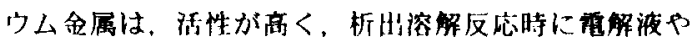
不粁物とのリチウム雨檑で起こる複雑な副反结が伙い， その充放電效率に大きな影需を与えている、リチウム は，選元加が強く，電解波に浸清しただけで，その表 面が反结すると言わ扎いる”。 Aurbauchらは、FT-IR

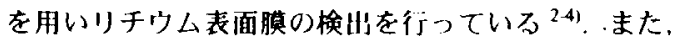
Takehara らは，XPS 测定により，リチウムの表面柫造 は二重㵒造になっていると報告している 有機電解筫溶液中のリチウム表而をラマン分沈法でそ の場测定した例は标めて少ない7.8)，本就文では， PC(Propylene Carbonate)単溶媒およぴ PC+EC (Ethylene Carbonate). PC+EC+DME (Dimethyl E(her)韲合溶媒门の) リチウム金属表面の影微ラマン分光測定法について検 討した結果を報告する。

\section{2 实}

Fig. 1 にラマン溂定用セルを示す。リチりムホイルを $5 \times 5 \mathrm{~mm}$ にカットし、これをラマン测定用セルに入れ電

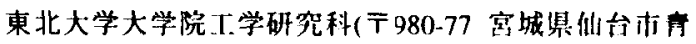
葉区荒巻字青葉) Graduate School of Engneering, Tohoku University (Aramaki aza aoba. Aoba-ku, Sendai 980-77 Japan )

Key Words: In sifu Raman Spectroscopy, Lithium Surface, Lithum Secondary Battery
解被を尤填した，PTFE 鄨セルの構造は，前面はレ一 ザ照射用の光学空, 背面はリチウムホイルを光学空に 抑しつけるための可動カラスロッドである. 光学密に は，Optical Flat な合成サフライア $30 \times 30 \times 0.3 \mathrm{~mm}$ を用 いた，セルの組访作業はすべてアルコン雾囲気のグロ

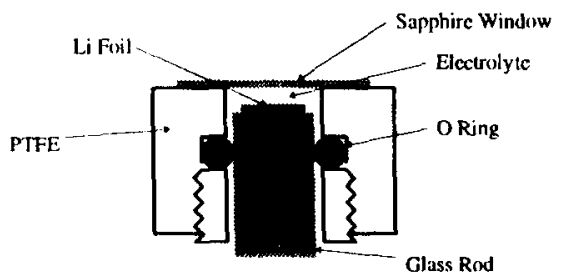

Fig. I The cell structure for in situ micriprobe spectrum measurements

一フポックス内で行った。実駼で用いた電解液は，1M $\left(\mathrm{M}=\mathrm{mol} / \mathrm{dm}^{3}\right) \mathrm{LiClO}_{4} / \mathrm{PC}, \mathrm{IM} \mathrm{LiClO} / / \mathrm{PC}+\mathrm{EC}(1: 1), 1 \mathrm{M}$ $\mathrm{LiClO}_{4} / \mathrm{PC}+\mathrm{EC}+\mathrm{DME}(1: 1: 1)$ で，三菱化学制である，浿定 セルは、ガスタイトな掼造にしてあり，測定時にグロ 一フホッッスから取り出しラマン測定に用いた.

分光系には日本分光製 NR-1800 㩆微ラマン分光装置 (トリプルモノクロ）上光電子増倍管を組み合わせて使 用した。ラマンスペクトルの测定波数筑用は100〜 $1700 \mathrm{~cm}^{-1}$ とし, 分解能は $2 \mathrm{~cm}^{-1}$ である. ラマンスペク トルの测定には約 3 時間を要した. 励起光はアルゴン イオンレーザー(波長 $514.5 \mathrm{~nm}$, 実効出力 $20 \mathrm{~mW}$ 以下)と し、レーザースポット $5 \mu$ 以下(対物レンズ×20)とした. 励起光をリチウムホイルの切り口に焦点を合わせ，リ 
チウム表面状態を観察しながら行った。

\section{3 䀦果と考嘉}

\section{1 表面生成物のラマンスペクトル湜定}

溶媒泣ラマン活性であるので，溶媒に起因するスペ クトルを極力排除する力法をとらない限り，表面生成

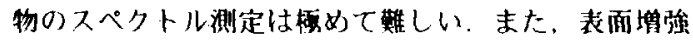
効果は期待できないので，リチり人表陑生成物のラマ ン散乱強度は檽めて小さく、光学悹材によるラマン綮 乱の影なども覞測スペクトルに重胃されてくる。

Fig.2 にホらケイ酸カラス (Cover Glass)，PYREX と合 成サファイアのラマンスペクトルの比較を示す。ホウ ケイ酸カラス（Cover Glass)や PYREX『密材として用 いた場合，幅の会いラマン線が、観测されるラマンス ペクトルに重胃すると予想される。 また，合成サファ イアを密材とした場合も重畩してくるが，合成サファ イソによって観测されるラマン線は線幅が狭く。 $800 \mathrm{~cm}^{-1}$ 以上の波数領域で比較的フラットであり， PYREXをを用いた場合よりもラマン線の州属は容易で ある，我々は、このような理由で合成サファイアを光 学空材として用いた．励起光によるリチウムの等損賃 を防ぐために，励起光強度は光学空位圆で約 $20 \mathrm{~mW}$ 以 下とした。

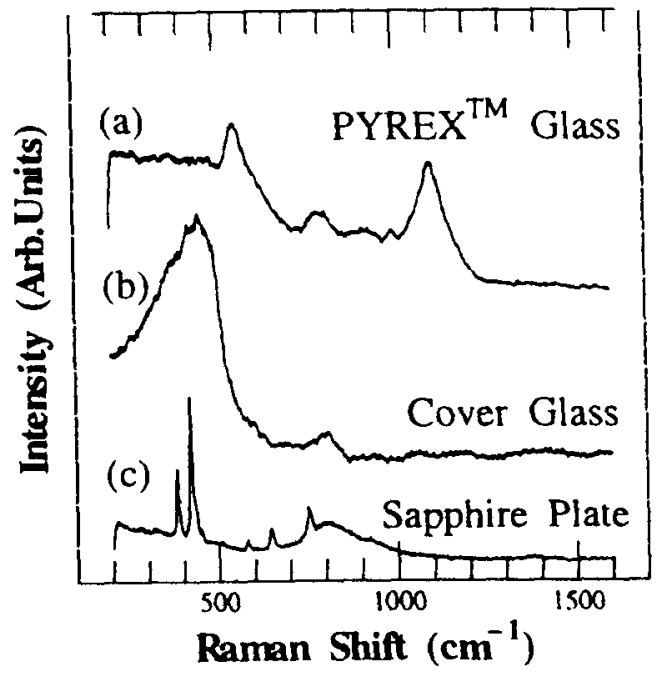

Fig. 2 Raman spectra of (a)PYREX ${ }^{\text {TM }}$ glass, (b)Cover glass, (c)Sapphire glass.
励起光強度を $100 \mathrm{~mW}$ 以上として測定を行った場合,リ チウム表面が変色したり，ラマンスペクトルのバック

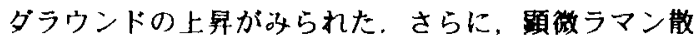
乱分炏法を用いるこににより，マクロなラマン散乱分 光法よりも微小な領域からのラマン散乱に関する情報 を得ることができた。すなおち，リチウム表面での， 比較的溶媒のかぶさりの少ない頜城を視覚的にとらえ， かつ不粁物の污染なぼが比較的少ないりチウムホイル の切りいに动起光の焦点を合わせ，その微小頜域から のみのラマンスペクトルを钼测した。

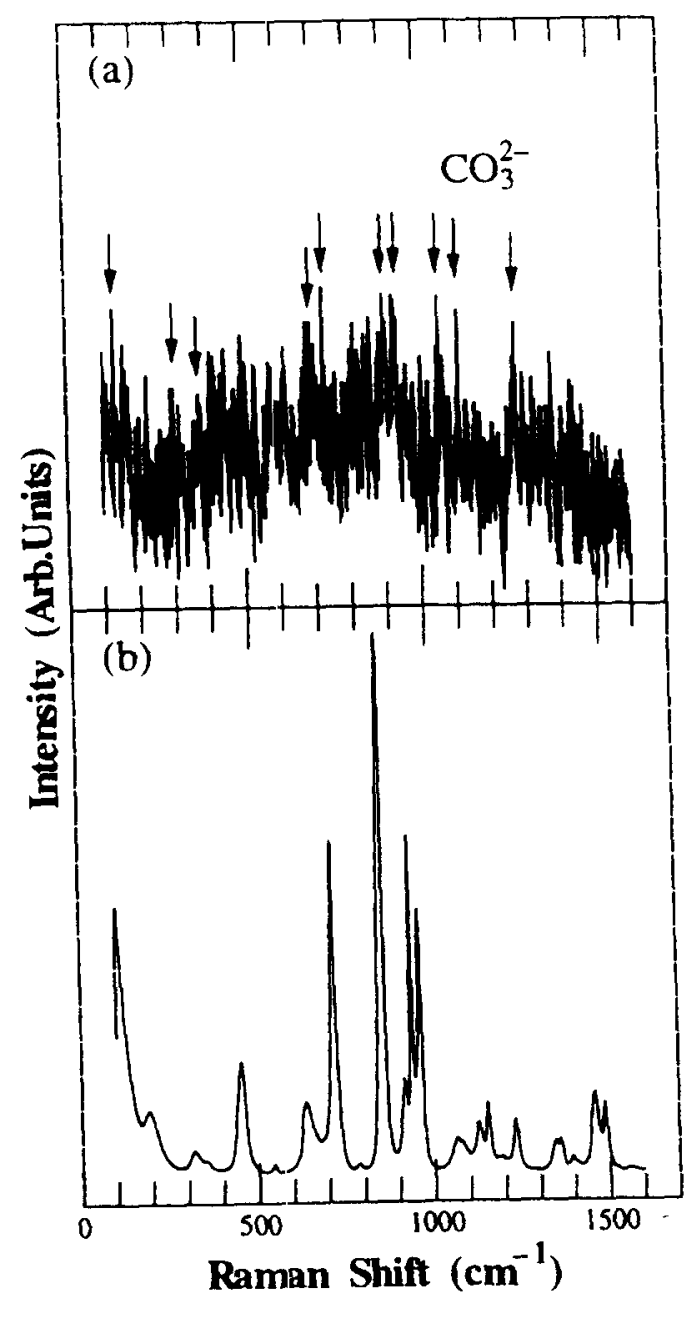

Fig. 3 (a) Raman spectrum of a $\mathrm{Li}$ surface in $1 \mathrm{M} \mathrm{LiClO}_{4} /$ PC. (b) Raman spectrum of bulk PC. 


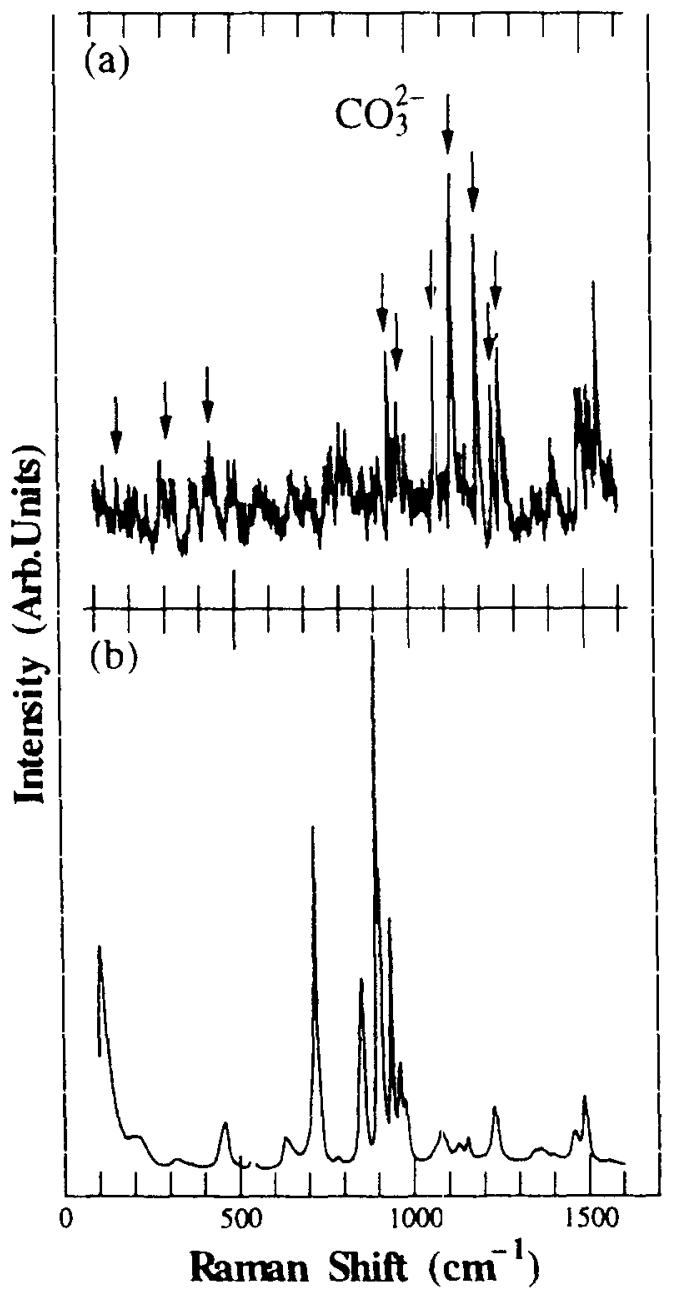

Fig. 4 (a) Raman spectrum of $\mathrm{Li}$ surface in $1 \mathrm{M} \mathrm{LiClO}_{4} / \mathrm{PC}+$ $\mathrm{EC}$ (b) Raman spectrum of bulk IM $\mathrm{LiClO}_{4} / \mathrm{PC}+\mathrm{EC}$.

\section{2 リチウム鈴蛙面のラマンスペクトル}

(1) $1 \mathrm{M} \mathrm{LiClO}_{4} / \mathrm{PC}$

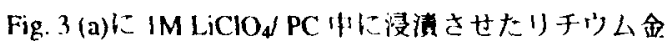
属表面からのラマンスペクトル，(b)にパルク $1 \mathrm{M}$ $\mathrm{LiClO}_{4} / \mathrm{PC}$ のラマンスペクトルを示す. (a)では，150, 300〜400. 600〜950, 1000〜1300 $\mathrm{cm}^{-1}$ にラマン線が钼 测された。我々は、これらのラマン線を(b)のバルク PC 液のラマンスペクトル，サファイアのラマンスペク トル, Aurbauch らによって報先さ扎た FT-IR のスペク トルと比較しラマン線の㷌属についての检封を行った。

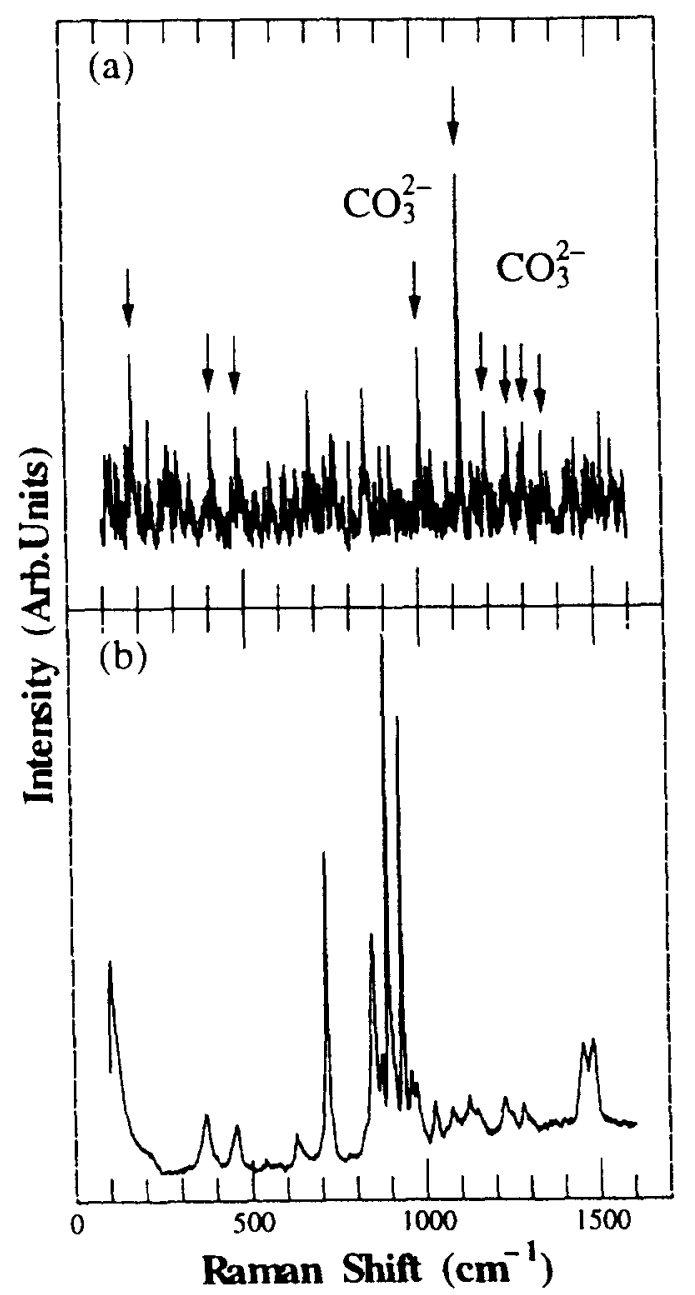

Fig. 5 (a) Raman spectrum of $\mathrm{Li}$ surface in $1 \mathrm{M} \mathrm{LiClO}_{4} / \mathrm{PC}+$ EC+DME (b) Raman spectrum of bulk $1 \mathrm{M} \mathrm{LiClO}_{4} / \mathrm{PC}+$ $\mathrm{EC}+\mathrm{DME}$.

その結果, $150 \mathrm{~cm}^{-1}$ はv(Li-OH)またはv(Li-CO3), 300〜 $400 \mathrm{~cm}^{-1}$ はサファイア空材，600〜950 $\mathrm{cm}^{-1}$ は，窓材川 チウム表面間に微量に介在する溶液成分，1000〜 $1300 \mathrm{~cm}^{-1}$ は $\mathrm{Li}$ 表面に存在する $\mathrm{CO}_{3}$ 対称伸篗振動による ものと同定された. $150 \mathrm{~cm}^{-1}$ のラマン楾についての同定 は、FT-IRなどによる報告例など、比较すべきデーター が少ないために、碓定はできない,一方, $1000 \sim 1300 \mathrm{~cm}^{-1}$

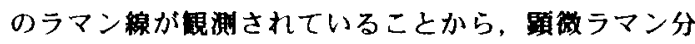
光法を用いた本実卧においても，リチウム表面の上で 
炭酸㙁化合物の生成が確認された。

(2) $1 \mathrm{M} \mathrm{LiClO}_{4} / \mathrm{PC}+\mathrm{EC}(1: 1)$

Fig. 4 (a)に IM LiClO4/PC+EC(1:1)帆に浸清させたり チウム金属表面からのラマンスペクトル，(b)にバルク $1 \mathrm{M} \mathrm{LiClO}_{4} / \mathrm{PC}+\mathrm{EC}(1: 1)$ ラマンスペクトルを示す．(a)で は. $100 \sim 200, \quad 350 \sim 420,900 \sim 10 \%), \quad 10(0) \sim 1350 \mathrm{~km}^{-1}$ にラマン線が観測された。これらのラマン線について (1)の場合と同橫に㷌属を行った。100〜20 $0 \mathrm{~cm}^{-1}$ のラマ ン線はv(Li-OH)またはv(Li-COH), 350～420 $\mathrm{cm}^{-1}$ はサファ

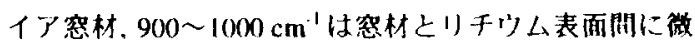
量に介在する溶液成分，1000 1350 $\mathrm{cm}^{-1}$ は Li 表面に存

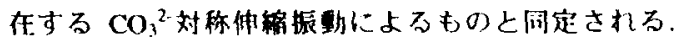
$\mathrm{CO}_{3}{ }^{2-}$ 対称伸樎振動によるラマン線は，帮味の $\mathrm{PC}$ を用 いた場合より多く顒测されたことから，リチウム表面 上に単味のPCの場合より多くの宸酸填化合物が存在 するものと考えられる。

(3) $\left.1 \mathrm{M} \mathrm{LiClO}_{4} / \mathrm{PC}+\mathrm{EC}+1\right) \mathrm{ME}(1: 1: 1)$

Fig. 5 に $\left.1 \mathrm{M} \mathrm{LiClO}_{4} / \mathrm{PC}+\mathrm{EC}+\mathrm{I}\right) \mathrm{ME}$ (1:1:1)のラマンスペ クトルを示す。(a)要解液に浸漬したし表解からのうマ ンスペクトル，(b)はバルク溶液のラマンスペクトルで ある. (a)では, $100 \sim 200,400 \sim 500,1100 \sim 1500 \mathrm{~cm}^{-1}$ にラマン線が覧测された。これらのラマン線について

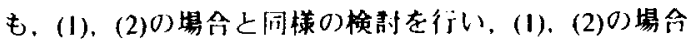
と同様に㷌属した。これらの結果より、リチりム表面 には炭酸㙁が存在する。. Aurbauchらは、FT-IRによる钼 察によってリチウム表而にはリチ门ムアルキルカーボ ネートが存在する数告をしている2゙ここで測定された ラマン線も。リチウムテルキルカーボネートケの $\mathrm{CO}_{3}{ }^{2}$ 対称伸䅛振動によるものであると考えられる。

本論文中では、リチウムを雪船液に侵した媵、約1 時間後に測起を行った結果について述へた。さらに， リチウムの金属光沢の保たれている㥜閒内で、ラマン スペクトルの溶液浸清時䦌俵你性を調べた。しかし。
浸倩時間を変化させても、ラマンスペクトルに影著な 変化は見られなかったことから，表面生成物は，雨解 液にりチウムを浸溃した淔後に生成したものと考えて いる.

\section{4 まとめ}

本誈女では、サファイア光学案を用いた PC 系溶液中 のリチりム金属表面の in situ影微ラマン分光法につい て叞告した。(1)リチウム表面上に $\mathrm{CO}_{3}{ }^{2}$ が存在すること がラマン敖乱によっても確認された（2)溶媒中のリチ 门ム金属表面に抽いて表面增強ラマン散乱(SERS)によ

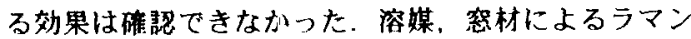
線が強く観測され州曆に注意を要することが示された。 目下, 我々は検出器をインテンシファイヤー付きマル チチャンネル㛟出器に変えて，さらに観測時間の短縮 化，高感度化の槐封を行っている。

\section{文 策}

I) E. Peled, J. Electrochem. Soc., 126, 2049 (1987).

2) D. Aurbach Year Ein-Ely and Arie Zaban, J. Electrochem. Soc., 144, Ll (1994).

3) D. Aurbach and Yosef Gofer, J. Electrochem. Soc:, 138, 3529 (1991).

4) D. Aurbach and Orit Chusid (youngman), $J$. Electrohem. Soc, 140, LIS5 (1993).

5) K. Kanamura, H. Tamura and Z. Takehara, J. Electroanal. Chem., 333, 127 (1992).

6) K. Kanamura,S. Shiraishi, H. Tamura and Z. Takehara, J. Electrochem. Sor., 141, 2379 (1994).

7) M. Odziemkowski, M. Krell and D. E. Irish, J. Electrochem. Soc, 139, 3052 (1992).

8) H. Tachikawa, Exploratory Techology Reserch ProgramEnergy \& Enviroment Division Final Report (1992). 